\title{
Apion miniatum Germ. Herbivory on the Mossy Sorrel, Rumex confertus Willd.: Induced Plant Volatiles and Weevil Orientation Responses
}

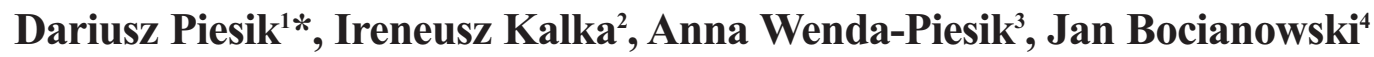 \\ 'Department of Entomology and Molecular Phytopathology, University of Technology and Life Sciences, \\ 85-225 Bydgoszcz, Kordeckiego 20, Poland \\ ${ }^{2}$ Lechpol Sp. z o.o., 89-200 Szubin, Jana Pawła II 36, Poland \\ ${ }^{3}$ Department of Plant Growth Principles and Experimental Methodology, \\ University of Technology and Life Sciences, 85-225 Bydgoszcz, Kordeckiego 20, Poland \\ ${ }^{4}$ Poznań University of Life Sciences, Department of Mathematical and Statistical Methods, \\ Wojska Polskiego 28, 60-637 Poznań, Poland \\ Received: 21 January 2014 \\ Accepted: 30 April 2014
}

\begin{abstract}
In this paper we report on the large induction of volatile organic compounds (VOCs) from a single leaf of the mossy sorrel, Rumex confertus Willd. (Polygonaceae), by herbivory of the red dock weevil (Apion miniatum Germ., Coleoptera: Apionidae). VOC blends induced by the red dock weevil herbivory included 5 green leaf volatiles (GLVs) ((Z)-3-hexenal, (E)-2-hexenal, (Z)-3-hexenol, (E)-2-hexenol, (Z)-3-hexen-1-yl acetate), two esters (benzyl acetate, methyl salicylate), and four terpenes ((Z)- $\beta$-ocimene, linalool, $\beta$ caryophyllene, (E)- $\beta$-farnesene). Not surprisingly, uninjured plants produced only small amounts of VOCs. A Y-tube experiment revealed that females of A. miniatum were attracted to the blend (blend 1) of (Z)-3-hexe$\mathrm{nal}+(\mathrm{E})-2$-hexenal $+(\mathrm{Z})-3$-hexenol $+(\mathrm{E})-2$-hexenol $+(\mathrm{Z})$-3-hexen-1-yl acetate at two concentrations of 1 and $5 \mathrm{ng} \cdot \mathrm{min}^{-1}$. In contrast males of the red dock weevil were not attracted to any tested concentration. Moreover, females and males of $A$. miniatum were not attracted to any concentration of blend 2 ((Z)-ocimene + linalool + benzyl acetate + methyl salicylate $+\beta$-caryophyllene $+(E)-\beta$-farnesene). Yet the red dock weevil females and males were repelled by the highest concentration $\left(125 \mathrm{ng} \cdot \mathrm{min}^{-1}\right)$ for both blends.
\end{abstract}

Keywords: Apion miniatum, red dock weevil, mossy sorrel, odors

\section{Introduction}

Plants are vulnerable to attack by organisms during their life, but even being immobile are not merely passive victims $[1,2]$. To protect themselves they have evolved an arsenal of physical and chemical defences [3-8]. There are many types of VOCs released by plants in response to insect attack (terpenes, fatty acid derivatives, benzenoids,

*e-mail: piesik@utp.edu.pl phenyl propanoids, and amino acid-derived metabolites) [9, 10]. Plant VOCs can be constitutively expressed, while those quantitatively or qualitatively induced after herbivory are often called herbivore-induced plant volatiles (HIPVs) $[11,12]$. Plant-induced VOCs defensive functions include directly deterring herbivores [13, 14], indirectly attracting natural enemies of attackers [15] and priming defences of uninjured organs on the same plant $[16,17]$. Thus uninjured plants can prime their metabolic machinery without investment costs of actual defence induction [18]. Yet a caveat of 
caution needs to be pointed out concerning ecological and evolutionary aspects of VOC induction [19]. An insect dose response to an individual plants VOCs can reveal the range of concentrations over which herbivore or parasitoid attraction or repellence occurs. A dose response to a VOC should indicate herbivore or predator or parasitoid sensitivity to a compound. By comparing dose responses across different VOCs induced after plant attack, the relative importance of VOCs can be suggested for primary and secondary consumers.

We examined interactions between Rumex confertus Willd. (Polygonaceae) and Apion miniatum Germ. (Coleoptera: Apionidae). Many Rumex spp. are serious weeds. Members of this family are very common perennial herbs growing mainly in the northern hemisphere, but various species have been introduced almost everywhere. In Western Australia, Rumex pulcher L. populations were greatly reduced in sites where Pyropteron doryliformis Ochsenheimer (Lepidoptera: Sesiidae) had been released [20]. In northern Victoria $P$. doryliformis (dock moth) established well on $R$. crispus [21, 22]. Moreover, Rumex species are used as food plants by the larvae of a number of Lepidoptera species. This is an interesting system involving a possible biological control agent of an invasive weed in Eastern Europe [23]. Classical biological control of weeds via the introduction of natural enemies from the native habitat of the weed is one of the most important methods to manage alien invasive weeds [24, 25] confirmed larval the development of Apion sp. in Miconia calvescens De Candolle (Melastomataceae) fruits. They found that the presence of Apion sp. on M. calvescens inflorescences is likely due to oviposition and feeding. Surveys in Israel in 1988 showed that the apionid weevil A. miniatum Germ. (Coleoptera: Apionidae) was damaging on Emex spinosa (L.) Campd. Subter. The larvae of A. miniatum develop in the stems, crown, and roots, and the adults make small holes in leaves of E. spinosa (Polygonaceae) [26]. The progression of the various biological control projects gives the opportunity to improve the science behind biological control and particularly to improve the safety, efficiency and efficacy of projects [27].

In the present study, we identified VOCs induced by a single $R$. confertus leaf after $A$. miniatum herbivory. We examined $R$. confertus constitutive and induced VOC emissions after $A$. miniatum herbivory to suggest VOCs of interest to test $A$. miniatum responses. Subsequently, we used Ytube behavioral experiments to test blend 1 and blend 2 responses of adult males and females of $A$. miniatum to five GLVs and six VOCs induced by $R$. confertus (to examine attraction/avoidance to injured and uninjured leaf $R$. confertus VOCs).

\section{Experimental Procedures}

\section{Plant Culture}

Experiments were performed in 2011 at the University of Technology and Life Sciences, Bydgoszcz, Poland in the
Plant Growth Center (PGC). In April 201030 mossy sorrel plants were dug up and transplanted to the PGC. One plant per pot was located in sterilized soil and maintained with supplemental light and ambient humidity. The photoperiod was $16 \mathrm{~L}: 8 \mathrm{D}$, daytime temperature was $22 \pm 2^{\circ} \mathrm{C}$, and overnight temperature was $18 \pm 2^{\circ} \mathrm{C}$. Two months after transplantation (June 2010), plants were randomly assigned to control and herbivory treatments for the VOC induction experiment.

\section{Infestation by the Red Dock Weevils}

One leaf of each $R$. confertus injury treatment plant was placed into a Nalophan bag $(\sim 50 \mathrm{~cm}$ high $\times 30 \mathrm{~cm}$ diam.; polyethylene terephtalate bags are odor- and taste-free cooking bags made of a plastic film resistant to decomposition in the temperature range from $-60^{\circ} \mathrm{C}$ to $+220^{\circ} \mathrm{C}$ (Charles Frères, Saint Etienne, France). Two newlyemerged pairs recognized by 'in copula' phase (two pairs were used due to lower size in comparison to Gastroidea sp.; previous experiments) were introduced to the Nalophane bag with one leaf of a plant while still attached to the plant. The plants were subjected to feeding for $24 \mathrm{~h}$. Weevils began to feed immediately when placed on a leaf placed in the Nalophan bag. The feeding insects were then removed immediately prior to VOC collection. Thus VOCs were measured from the injured leaf and not from the weevils.

\section{Volatile Collection System (VCS)}

Volatiles were collected simultaneously from enclosed $R$. confertus plants from 10 a.m. to 1 p.m. (sunny days during all measurements). Odors were collected for $3 \mathrm{~h}$ from one leaf (both of each control or injury treatment plant).

Eight days of measurements were required (20 herbivory treatment plants, 10 control plants, and 2 blanks (empty Nalophan bags)), because the VCS apparatus was set up to collect VOCs from four plants simultaneously. A volatile collector trap (6.35-mm-OD (outside diameter), 76mm-long glass tube; Analytical Research Systems, Inc., Gainesville, Florida, USA) containing $30 \mathrm{mg}$ of Super-Q (Alltech Associates, Inc., Deerfield, Illinois, USA) adsorbent was inserted into each of four Tygon tubes (connection between airflow meter and collector trap). Purified humidified air was delivered at a rate of $601 \cdot h^{-1}$ over the plants. A vacuum pump sucked $20 \%$ less air $\left(48 \mathrm{l} \cdot \mathrm{h}^{-1}\right)$ to avoid collecting odors from any gap of the system.

\section{Analytical Methods}

Volatiles were eluted from each Super-Q collection trap with $225 \mu \mathrm{L}$ of hexane containing $7 \mathrm{ng}$ of decane as an internal standard. Volatiles were analyzed by coupled gas chromatography-mass spectrometry (GC-MS). A GC Perkin Elmer AutoSystem XL was fitted with a 30-m DB$5 \mathrm{MS}$ capillary column $(0.25$-mm-ID, $0.25 \mu \mathrm{m}$ film thickness; Restek, Bellefonte, PA, USA). The temperature program increased the chromatography oven temperature from 
Table 1. Descriptive statistics for values of the VOCs.

\begin{tabular}{|c|c|c|c|c|c|c|c|c|c|}
\hline \multicolumn{2}{|c|}{ VOCs } & Min. & Mean & Median & Max. & $\mathrm{Sd}$ & Skewness & Kurtosis & $\mathrm{CV}$ \\
\hline \multirow{2}{*}{ Z-3-HAL } & treatment & 359.8 & 473.5 & 491.6 & 608.7 & 66.28 & -0.0536 & -0.6156 & 14.00 \\
\hline & control & 0.5 & 2.38 & 2.6 & 4.2 & 1.394 & -0.0719 & -1.491 & 58.57 \\
\hline \multirow{2}{*}{ E-2-HAL } & treatment & 34.7 & 49.85 & 48.65 & 64.7 & 9.479 & -0.0552 & -1.114 & 19.02 \\
\hline & control & 0.8 & 1.51 & 1.4 & 2.4 & 0.599 & 0.435 & -1.157 & 39.67 \\
\hline \multirow{2}{*}{ Z-3-HOL } & treatment & 34.8 & 48.88 & 49.35 & 61.4 & 7.144 & -0.3233 & -0.5303 & 14.62 \\
\hline & control & 0 & 0.73 & 0.8 & 1.4 & 0.4945 & -0.3054 & -1.202 & 67.74 \\
\hline \multirow{2}{*}{ E-2-HOL } & treatment & 10.1 & 18.73 & 19.9 & 34.2 & 5.647 & 0.6156 & 1.028 & 30.15 \\
\hline & control & 0 & 0.21 & 0.2 & 0.4 & 0.1595 & 0.00346 & -1.444 & 75.95 \\
\hline \multirow{2}{*}{ Z-3-HAC } & treatment & 348.7 & 504 & 478.5 & 658.9 & 90.38 & 0.2893 & -0.9486 & 17.93 \\
\hline & control & 0.9 & 3.89 & 4.4 & 6.2 & 1.795 & -0.5102 & -1.069 & 46.14 \\
\hline \multirow{2}{*}{ Z-OCI } & treatment & 86.9 & 126.6 & 123.8 & 178.4 & 27.38 & 0.2139 & -1.122 & 21.63 \\
\hline & control & 0.4 & 1.53 & 1.55 & 2.4 & 0.6584 & -0.473 & -0.8818 & 43.03 \\
\hline \multirow{2}{*}{ LIN } & treatment & 345.8 & 430.1 & 426.8 & 604.2 & 63.15 & 0.9143 & 0.9974 & 14.68 \\
\hline & control & 0.4 & 2.58 & 2.8 & 4.7 & 1.437 & -0.1555 & -1.202 & 55.70 \\
\hline \multirow{2}{*}{$\mathrm{BAC}$} & treatment & 16.8 & 26.01 & 24.7 & 38.5 & 6.83 & 0.3649 & -1.019 & 26.26 \\
\hline & control & 0 & 0.365 & 0.25 & 1.2 & 0.3986 & 1.009 & -0.1056 & 109.21 \\
\hline \multirow{2}{*}{ MAT } & treatment & 12.8 & 25.8 & 35.15 & 40.2 & 8.403 & 0.08318 & -1.197 & 32.57 \\
\hline & control & 0 & 0.7 & 0.55 & 2.1 & 0.6307 & 1.02 & 0.4548 & 90.10 \\
\hline \multirow{2}{*}{$\beta$-CAR } & treatment & 324.8 & 392 & 398.6 & 462.1 & 35.74 & 0.1078 & -0.5295 & 9.12 \\
\hline & control & 0.4 & 1.46 & 1.45 & 2.4 & 0.7486 & -0.2658 & -1.398 & 51.27 \\
\hline \multirow{2}{*}{$\beta$-FAR } & treatment & 698.7 & 837.1 & 844.2 & 962.4 & 64.22 & -0.2165 & -0.2628 & 7.67 \\
\hline & control & 0.5 & 2.02 & 2.25 & 3.5 & 1.15 & -0.1215 & -1.421 & 56.93 \\
\hline
\end{tabular}

$\mathrm{Sd}$ - standard deviation

$\mathrm{CV}$ - coefficient of variation [in \%]

$40^{\circ} \mathrm{C}$ to $200^{\circ} \mathrm{C}$ at $5^{\circ} \mathrm{C} \cdot \mathrm{min}^{-1}$. The compounds were ordered on the chromatogram by their retention time and IDs were initially determined by matches to known compounds in the NIST 1998 database. A commercially available standard of each compound was run to confirm each plant VOC ID. Peaks were integrated from each GC-chromatogram and compared to the corresponding internal standard peak to calculate constitutive and induced VOC concentrations.

\section{Y-tube Apion miniatum Behavior}

Weevils were tested with one blend of five synthetic GLVs (Z)-3-hexenal + (E)-2-hexenal + (Z)-3-hexenol + (E)-2-hexenol + (Z)-3-hexen-1-yl acetate], and a second blend consisting of six VOCs [Z)-ocimene + linalool + benzyl acetate + methyl salicylate $+\beta$-caryophyllene $+(E)-\beta$ farnesene]. All components (95\% purity) were purchased from Sigma-Aldrich. The Y-tube system used was similar to that described by Piesik et al. [28]. Each blend was tested at 5 concentrations $\left(0,1,5,25,125 \mathrm{ng} \cdot \mathrm{min}^{-1}\right)$. Each individual VOC was present in a blend at the specified concen- tration. Thus for instance for the GLVs blend $1 \mathrm{ng} \cdot \mathrm{min}^{-1}$ means that $1 \mathrm{ng}(\mathrm{Z})-3$-hexenal $+1 \mathrm{ng}(\mathrm{E})$-2-hexenal $+1 \mathrm{ng}$ (Z)-3-hexenol + 1 ng (E)-2-hexenol + 1 ng (Z)-3-hexen-1$\mathrm{yl}$ acetate was added to $50 \mu \mathrm{l}$ hexane. A dose of a blend was placed in one arm of the Y-tube and tested against $50 \mu \mathrm{l}$ hexane without the blend $\left(0 \mathrm{ng} \cdot \mathrm{min}^{-1}\right)$. The tubes were washed and rotated to limit the effects of chemical residues from previous bioassay subjects on the current test subject. Of each sex, 20 newly-emerged ( $\leq 1$-day-old) adults (with fully developed olfactory sensory systems) were tested at each concentration of each blend, with each insect tested once. All tested adults chose an arm of the Y-tube within 3 $\min$.

\section{Data Analysis}

The descriptive statistics (mean, median, minimal and maximal values, standard deviation, skewness and kurtosis, and coefficient of variation) were used to report the VOCs quantities and their distribution as well as the variations recorded by the GC-MS from the injured and control 
leaves. The relationships between 11 compounds were estimated using Pearson's correlation coefficients, since there were no deviations from the normal distribution. All relationships were presented in the form of a scatterplot and the significant correlations in linear form [29].

Chi-square goodness of fit tests (X2-test), with the Yates correction for small samples $(1 \times 2)$, were conducted to indicate whether the choice of Y-tube arms was influenced by a preference for odor source (plant bouquet vs. hexane solvent; or synthetic blend vs. hexane solvent) at each exposure concentration $\times \operatorname{sex} \times$ exposure duration combination. Nonsignificant tests indicated that the observed beetle counts did not significantly deviate from an expected ratio of 10:10 (hexane solvent only arm:plant bouquet or synthetic blend). Significant tests indicated attraction (more individuals chose Y-tube arm with a plant bouquet or synthetic blend) or repellency (more individuals chose the Y-tube arm with only hexane solvent). All statistical tests were conducted using SAS version 9.2 [30] (significance threshold $\alpha=0.05$ ).

\section{Results}

\section{Volatiles after Insect-Caused Foliar Damage}

The greatest quantities of volatiles released by mossy sorrel plants after injury by red dock weevil were recorded for $\beta$-FAR, Z-3-HAC, Z-3-HAL, LIN, and $\beta$-CAR with the mean values respectively: 837, 504, 473, 430, and 399 $\mathrm{ng} \cdot \mathrm{h}^{-1}$. Much smaller amounts of volatile compounds related to the following: Z-OCI, E-2-HAL, Z-3-HOL, BAC, MAT, and E-2-HOL with the means from 18.7 to $127 \mathrm{ng} \cdot \mathrm{h}^{-1}$ (Table 1, Fig. 1). Based on the skewness and kurtosis calculations we conclude that results represent the distribution similar to the normality, not exceeding the threshold values. The greatest variations were recorded in the case of MAT and E-2-HOL $(\mathrm{Cv}>30 \%)$, while the smallest for $\beta$-FAR and $\beta$-CAR $(\mathrm{Cv}<10 \%)$. The control plants released trace amounts of VOCs ranging from 0.21 (E-2-HOL) to 3.89 $n g \cdot h^{-1}(Z-3-H A C)$ with a very high variability of their release.

The simultaneous release of certain volatile compounds altered positive correlation nature, as in the case of: BAC and $\mathrm{Z}-3-\mathrm{HOL}(\mathrm{r}=0.51), \mathrm{BAC}$ and $\mathrm{Z}-\mathrm{OCI}(\mathrm{r}=0.57), \beta-\mathrm{CAR}$ and $\mathrm{Z}-\mathrm{OCI}(\mathrm{r}=0.52)$, and MAT and BAC $(\mathrm{r}=0.4538)$. Meanwhile a negative relationship was found in the case of Z-OCI and Z-3-HAL ( $\mathrm{r}=-0.45), \mathrm{Z}-3-\mathrm{HAC}$, and E-2-HAL ( $\mathrm{r}=-0.58)$, (Fig. 2). For the vast majority of volatile compounds there were no significant relationships, as shown in Fig. 1.

\section{Y-tube Behavior of $A$. miniatum}

We found that weevils chose one arm of the Y-tube usually within $2 \mathrm{~min}$. Chi-square tests revealed that female $A$.

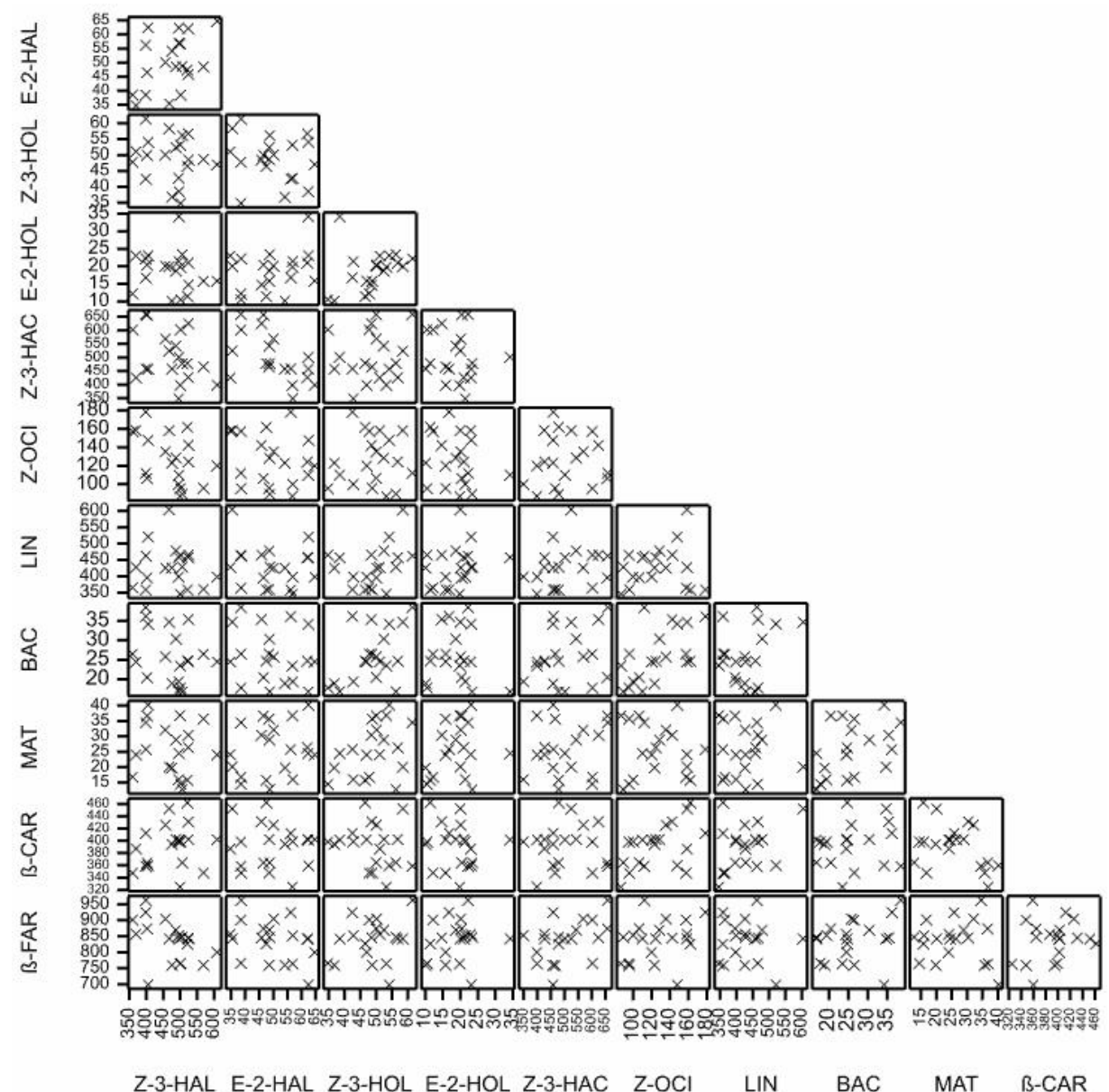

Fig. 1. Scatterplot matrix of relationships among VOCs (Z-3-HAL, E-2-HAL, Z-3-HOL, E-2-HOL, Z-3-HAC, Z-OCI, LIN, BAC, MAT, $\beta$-CAR, $\beta$-FAR) $\left(\mathrm{ng}^{-1} \mathrm{~h}^{-1}\right)$. 
Table 2. Effect of one synthetic blend 1 of five GLVs $[(Z)-3-H A L+(E)-2-H A L+(Z)-3-H O L+(E)-2-H O L+(Z)-3-H A C]$, and a second synthetic blend 2 of six VOCs $[(Z)-O C I+$ LIN + BAC + MAT $+\beta-C A R+\beta-F A R]$ on the number of $A$. miniatum adult females and males choosing to enter a Y-tube arm containing the blend odor or the Y-tube arm containing purified humidified air and hexane solvent (no odor).

\begin{tabular}{|c|c|c|c|c|c|c|c|c|}
\hline $\begin{array}{l}\text { Name of mixed } \\
\text { compounds }\end{array}$ & Dose & $\mathrm{ng} \cdot \mathrm{min}^{-1}$ & $+^{(4)}$ & $-{ }^{(5)}$ & $\chi^{2(1)}$ & $+(4)$ & $-{ }^{(5)}$ & $\chi^{2(1)}$ \\
\hline (Z)-3-HAL & control & 0.0 & 10 & 10 & $0.05 \mathrm{~ns}$ & 12 & 8 & $0.45 \mathrm{~ns}$ \\
\hline$+(\mathrm{E})-2-\mathrm{HAL}$ & 1 & 1 & 16 & 4 & $6.05^{*}(\mathrm{a})^{(3)}$ & 7 & 13 & $1.25 \mathrm{~ns}$ \\
\hline$+(\mathrm{Z})-3-\mathrm{HOL}$ & 2 & 5 & 15 & 5 & $4.05^{*}(\mathrm{a})^{(3)}$ & 8 & 12 & $0.45 \mathrm{~ns}$ \\
\hline$+(\mathrm{E})-2-\mathrm{HOL}$ & 3 & 25 & 4 & 16 & $6.05^{*}(\mathrm{r})^{(2)}$ & 11 & 9 & $0.05 \mathrm{~ns}$ \\
\hline$+(\mathrm{Z})-3-\mathrm{HAC}$ & 4 & 125 & 3 & 17 & $8.45^{* *}(\mathrm{r})^{(2)}$ & 5 & 15 & $4.05^{*}(\mathrm{r})^{(2)}$ \\
\hline Z-OCI & control & 0.0 & 12 & 8 & $0.45 \mathrm{~ns}$ & 8 & 12 & $0.45 \mathrm{~ns}$ \\
\hline$+\mathrm{LIN}$ & 1 & 1 & 6 & 14 & $2.45 \mathrm{~ns}$ & 9 & 11 & $0.05 \mathrm{~ns}$ \\
\hline$+\mathrm{BAC}$ & 2 & 5 & 3 & 17 & $8.45^{* *}(\mathrm{r})^{(2)}$ & 7 & 13 & $1.25 \mathrm{~ns}$ \\
\hline+ MAT & 3 & 25 & 3 & 17 & $8.45^{* *}(\mathrm{r})^{(2)}$ & 4 & 16 & $6.05 *(\mathrm{r})^{(2)}$ \\
\hline$+\beta$-CAR & 4 & 125 & 2 & 18 & $11.25^{* * *}(\mathrm{r})^{(2)}$ & 4 & 16 & $6.05^{*}(\mathrm{r})^{(2)}$ \\
\hline$+\beta$-FAR & & & & & & & & \\
\hline
\end{tabular}

(1) level of significance (ns-not significant), $\left({ }^{*} \mathrm{p}<0.05\right),\left({ }^{* *} \mathrm{p}<0.01\right),\left({ }^{* * *} \mathrm{p}<0.001\right)$

(2) $\mathrm{r}$ - repellent

(3) $\mathrm{a}$ - attractant

(4) + Y-tube arm with tested amount of the compound, volatile diluted in hexane emitted from filter paper

(5) - Y-tube arm only with hexane emitted from filter paper
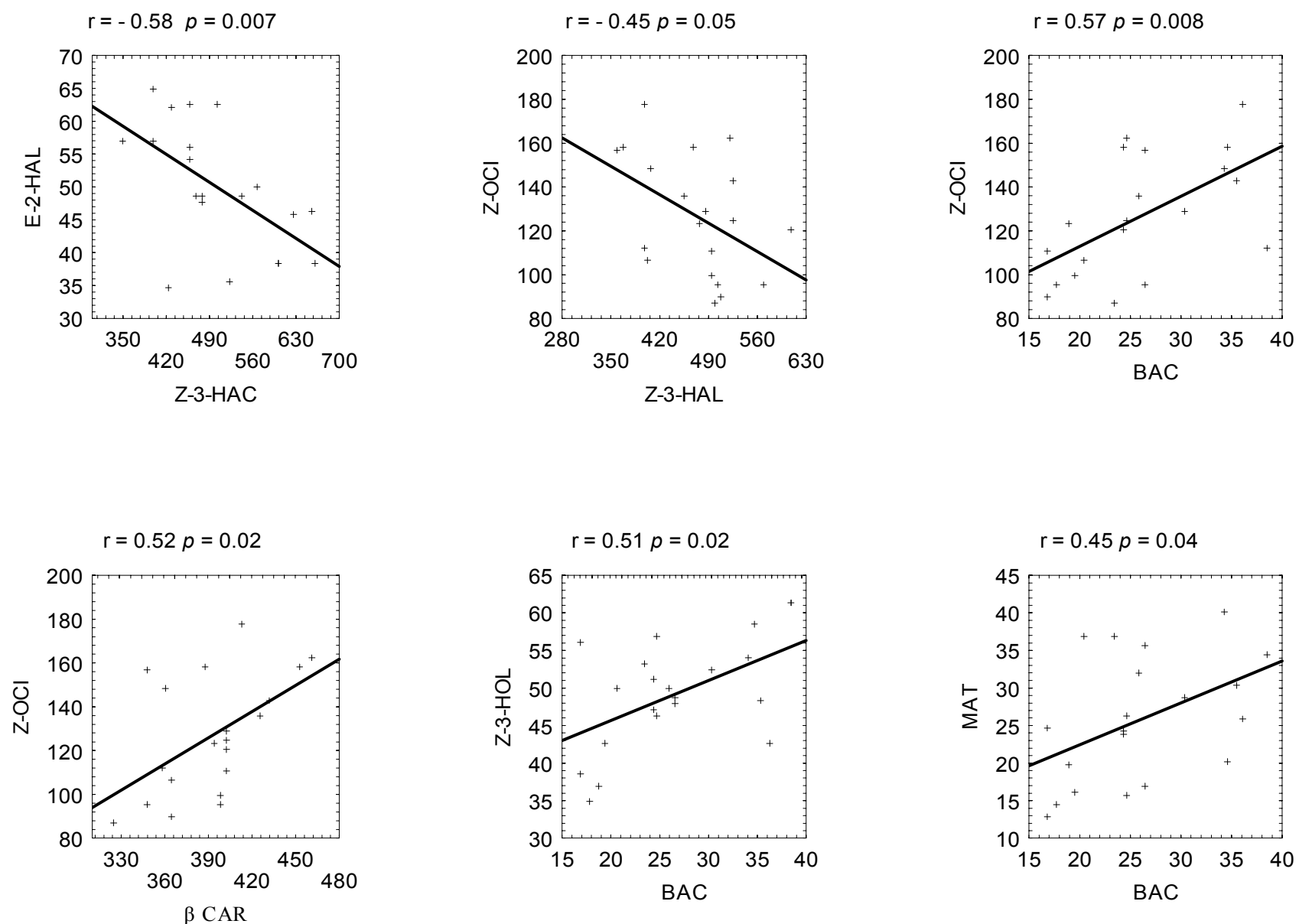

Fig. 2. Significant correlations between amounts of VOC based on r-Pearson coefficients $\left(\mathrm{ng} \cdot \mathrm{h}^{-1}\right)$. 
miniatum were significantly attracted at 1 and $5 \mathrm{ng} \cdot \mathrm{min}^{-1}$ to blend 1 (Table 2). No attractive concentration for both blends was observed in the responses of males. Yet the red dock weevil females were repelled by the concentrations of 25 and $125 \mathrm{ng} \cdot \mathrm{min}^{-1}$ for blend 1 and 5, 25, $125 \mathrm{ng} \cdot \mathrm{min}^{-1}$ for blend 2. Males seemed to be less sensitive and were repelled by one concentration $\left(125 \mathrm{ng} \cdot \mathrm{min}^{-1}\right)$ of blend 1 and two concentration $\left(25,125 \mathrm{ng} \cdot \mathrm{min}^{-1}\right)$ of blend 2 .

\section{Discussion of Results}

In the first part of our experiment, we confirmed that $A$. miniatum herbivory dramatically induced 11 VOCs from mossy sorrel plants, all of which are common injuryinduced GLVs, terpenes, and an aromatic compound [31, 32]. Abiotic injury often induces GLVs while terpene and indole induction often requires actual herbivore feeding injury [33]. However, pathogen infection also can induce GLVs and terpenes [34]. VOCs can be involved in direct and indirect plant defenses against herbivores or pathogens $[35,36]$. VOCs were released from control plants only in small but detectable amounts.

In the second Y-tube behavioral experiment, we chose to use equal amounts of each VOC in the blend for a given test dose. Thus the ratios of synthetic blend VOCs encountered by test herbivores likely differ from the ratio of these compounds in natural plant VOC bouquets. Under Y-tube conditions only females of $A$. miniatum responded positively to concentrations 1 and $5 \mathrm{ng} \cdot \mathrm{min}^{-1}$ of blend 1 . However, females were significantly repelled by the highest concentrations of tested blend 1 (25 and 125 $\left.\mathrm{ng} \cdot \mathrm{min}^{-1}\right)$. Thus females of the red dock weevil might use small amounts of mossy sorrel GLVs for host-plant searching.

The above results are in good agreement with those from the congener $G$. viridula with $R$. confertus [37] and $G$. polygoni with $R$. confertus [38]. Thus herbivory on a single $R$. confertus leaf by $G$. polygoni and $G$. viridula could result in similar adult conspecific and congeneric VOC behavioral responses to injured plants. Our study and both previous studies suggest that A. miniatum, G. polygoni, and $G$. viridula use GLVs from injured leaves to find lightly injured (single leaf) host plants, but may avoid highly injured plants. This inference depends on the degree of VOC induction increasing with $A$. miniatum herbivory intensity on $R$. confertus and needs to be tested in the field. Piesik et al. [28] found that only female Cephus cinctus Norton (Hynenoptera: Cephidae) were attracted to some concentrations of (Z)-3-HAC, (Z)-3-HOL, and the terpene $\beta$-ocimene. Yet $C$. cinctus females were repelled by the highest tested concentration $\left(8,400 \mathrm{ng} \cdot \mathrm{h}^{-1}\right)$ of (Z)-3-HAC. With maize (VOCs induced by Fusarium infection), behavioral tests found attraction to synthetic components for adult cereal leaf beetles Oulema melanopus L. (Coleoptera: Chrysomelidae) at 7,500 $\mathrm{ng} \cdot \mathrm{h}^{-1}$ for two GLVs ((Z)-3-HAL, (Z)-3-HAC) and two terpenes (LIN \& BCAR), and attraction at lower doses of $60 \mathrm{ng} \cdot \mathrm{h}^{-1}$ for both GLVs and $300 \mathrm{ng} \cdot \mathrm{h}^{-1}$ for LIN. In contrast, Carroll et al. [39] showed with Y-tube tests that crawling larval Spodoptera frugiperda Walker (Lepidoptera: Noctuidae) were attracted to injured maize over uninjured plants, to a wide range of LIN concentrations, and undamaged plants with LIN added (and even linalool alone) were much more attractive than uninjured plant bouquets. There are often synergistic effects of VOC blends on insect attraction or repellence, so only certain VOCs of a plant bouquet may influence insect behavior [40, 41].

VOC induction effects on plants will need further investigation to explore the ecological role of these active substances [42]. It is well known that manipulation of volatile emission in plants has enormous potential in relationship to pest management in agricultural contexts [43]. Manipulating these signals may help increase the effectiveness of attracting parasitoid and predatory natural enemies with induced VOCs to more effectively serve as biological control agents in agroecosystems. Although testing biotic agent responses to full plant VOC mixtures is ecologically more realistic, it leads to a far more difficult experimental approach to determine the relative importance of cues in an injured plant's VOC bouquet. Yet testing biotic agent (including plant) dose responses to blends may help to decipher VOC informational content [44, 45].

\section{Abbreviations}

VOCs - volatile organic compounds

HIPVs - herbivore-induced plant volatiles

GLVs - green leaf volatiles

(Z)-3-hexenal - (Z)-3-HAL

(E)-2-hexenal - (E)-2-HAL

(Z)-3-hexenol - (Z)-3-HOL

(E)-2-hexenol - (E)-2-HOL

(Z)-3-hexen-1-yl acetate - (Z)-3-HAC

(Z)- $\beta$-ocimene - (Z)-OCI

linalool - LIN

benzyl acetate - BAC

methyl salicylate - MAT

$\beta$-caryophyllene $-\beta$-CAR

(E)- $\beta$-farnesene $-\beta$-FAR

\section{Acknowledgements}

Dariusz Piesik thanks Magdalena Piesik (Nicolaus Copernicus University, Ludwik Rydygier Collegium Medicum in Bydgoszcz, Poland) for her invaluable assistance with experimental work. The experiments were done at the laboratory of the Regional Center for Innovation (RCI) - University of Technology and Life Sciences in Bydgoszcz.

\section{References}

1. DICKE M., VAN LOOP J. J. A., SOLER R. Chemical complexity of volatiles from plants induced by multiple attack. 
Nature Chem. Biol. 5, 317, 2009.

2. RASMANN S., KÖLLNER T. G., DEGENHARDT J. HILTPOLD J., TÖPFER S., KUHLMANN U., GERSHENZON J., TURLINGS T. C. J. Recruitment of entomophatogenic nematodes by insect-damaged maize roots. Nature 434, 732, 2005.

3. ARIMURA G., KOST C., BOLAND W. Herbivoreinduced, indirect plant defences. Biochim. Biophys. Acta 1734, 91, 2005.

4. HALITSCHKE R., STENBERG J. A., KESSLER D., KESSLER A., BALDWIN I. T. Shared signals - "alarm calls" from plants increase apparency to herbivores and their enemies in nature. Ecol. Lett. 11, 24, 2008.

5. HOLOPAINEN J. K., GERSHENZON J. Multiple stress factors and the emission of plant VOCs. Trends Plant Sci. 15, 176, 2010.

6. KESSLER A., BALDWIN I. T. Plant responses to insect herbivory: the emerging molecular analysis. Annu. Rev. Plant Phys. 53, 299, 2002.

7. SCHOONHOVEN L. M., VAN LOON J. J. A., DICKE M. Insect-Plant Biology. Oxford University Press, 2005.

8. VICKERS C. E., GERSHENZON J., LERDAU M. T., LORETO F. A unified mechanism of action for volatile isoprenoids in plant abiotic stress. Nat. Chem. Biol. 5, 283, 2009.

9. BALDWIN I. T., HALITSCHKE R., PASCHOLD A., VON DAHL C. C., PRESTON C.A. Volatile signaling in plantplant interactions: "Talking trees" in the genomics era. Science 311, 812, 2006.

10. DUDAREVA N., PICHERSKY E. Metabolic engineering of plant volatiles. Curr. Opin. Biotech. 19, 181, 2008.

11. PIESIK D., ŁYSZCZARZ A., TABAKA P., LAMPARSKI R., BOCIANOWSKI J., DELANEY K. J. Volatile induction of three cereals: influence of mechanical injury and insect herbivory on injured plants and neighboring uninjured plants. Ann. Appl. Biol. 157, 425, 2010.

12. VAN DEN BOOM C. E. M., VAN BEEK T. A., POSTHUMUS M. A., DE GROOT A., DICKE M. Qualitative and quantitative variation between volatile profiles induced by Tetranychus urticae feeding on different plants of various families. J. Chem. Ecol. 30, 69, 2004.

13. LAOTHAWORNKITKUL J., PAUL N. D., VICKERS C. E., POSSELL M., TAYLOR J. E., MULLINEAUX P. M., HEWITT C. N. Isoprene emissions influence herbivore feeding decisions. Plant Cell Environ. 31, 1410, 2008

14. UNSICKER S. B., KUNERT G., GERSHENZON J. Protective perfumes: the role of vegetative volatiles in plant defense against herbivores. Curr. Opin. Plant Biol. 12, 479, 2009.

15. MUMM R., POSTHUMUS M. A., DICKE M. Significance of terpenoids in induced indirect plant defence against herbivorous arthropods. Plant Cell Environ. 31, 575, 2008.

16. FROST C. J., APPEL H. M., CARLSON J. E., DE MORAES C. M., MESCHER M. C., SCHULTZ J. C. Within-plant signalling via volatiles overcomes vascular constraints on systemic signalling and primes responses against herbivores. Ecol. Lett. 10, 490, 2007.

17. HEIL M., SILVA BUENO J. C. Within-plant signalling by volatiles leads to induction and priming of an indirect plant defence in nature. P. Natl. Acad. Sci. USA 104, 5467, 2007.

18. RODRIGUEZ-SAONA C. R., RODRIGUEZ-SAONA L. E., FROST C. J. Herbivore-induced volatiles in the perennial shrub, Vaccinium corymbosum, and their role in interbranch signaling. J. Chem. Ecol. 35, 163, 2009.

19. KESSLER A., HEIL M. The multiple faces of indirect defences and their agents of natural selection. Funct. Ecol.
25, 348, 2011.

20. FOGLIANI R. G., STRICKLAND G. R. Final report to Meat and Livestock Australia, Project DAW .045 1995-1999. Department of Agriculture [WA]/Meat and Livestock Australia, 2000.

21. MORLEY T. B., FAULKNER S., FAITHFULL I. G. Proceedings of the Australian Weeds Conference. Weed Society of New South Wales, Sydney, pp. 381-384, 2004

22. MORLEY T. B., MORIN L. Progress on Boneseed (Chrysanthemoides monilifera subsp. monilifera (L.) Norlindh) Biological Control: The Boneseed Leaf Buckle Mite Aceria (Keifer) sp., the Lacy-winged Seed Fly Mesoclanis magnipalpis Bezzi and the Boneseed Rust Endophyllum osteospermi. Plant Prot. Quart. 23, 29, 2008.

23. PIESIK D. The occurrence of Gastroidea viridula Deg. and Gastroidea polygoni L. on Rumex confertus Willd. as biological representatives of weed population control. J. Plant Prot. Res. 40, 219, 2000.

24. DENSLOW J. S., JOHNSON M. T. Biological Control of Tropical Weeds: Research Opportunities in Plant-Herbivore Interactions. Biotropica 38, 139, 2006.

25. BADENES-PEREZ F. R., JOHNSON M. T. Ecology and impact of Allorhogas sp. (Hymenoptera: Braconidae) and Apion sp. (Coleoptera: Curculionoidea) on fruits of Miconia calvescens DC (Melastomataceae) in Brazil. Biol. Control 43, 317, 2007.

26. SCOTT J. K., YEOH P. B.,WOODBURN T. L. Procedings X International Symposium on Biological Control of Weeds, MSU, Bozeman, Montana, USA, Neal R. Spencer [ed.]. pp. 473-485, 2000.

27. PALMER W. A., HEARD T. A., SHEPPARD A. W. A review of Australian classical biological control of weeds programs and research activities over the past 12 years. Biol. Control 52, 271, 2010.

28. PIESIK D., WEAVER D. K., RUNYON J. B., BUTELER M., PECK G. E., MORRILL W. L. Behavioral responses of wheat stem sawflies to wheat volatiles. Agric. Forest Entomol. 10, 245, 2008.

29. KOZAK M., BOCIANOWSKI J., RYBIŃSKI W. Note on the use of coefficient of variation for data from agricultural factorial experiments. J. Agric. Sci. 19, 644, 2013.

30. SAS Institute. SAS user's guide: statistics, version 9.2. SAS Institute, Cary, NC., 2007.

31. ENGELBERTH J., ALBORN H. T., SCHMELZ E. A., TUMLINSON J. H. Airborne signals prime plants against insect herbivore attack. P. Natl. Acad. Sci. USA 101, 1781, 2004.

32. KESSLER A., BALDWIN I. T. Defensive function of herbivore-induced plant volatile emissions in nature. Science 291, 2141, 2001.

33. HARE J. D. Ecological role of volatiles produced by plants in response to damage by herbivorous insects. Annu. Rev. Entomol. 56, 161, 2011.

34. PIESIK D., PAŃKA D., JESKE M., WENDA-PIESIK A., DELANEY K. J., WEAVER D. K. Volatile induction of infected and neighboring uninfected plants potentially influence attraction/repellence of a cereal herbivore. J. Appl. Entomol. 137, 296, 2013.

35. DUDAREVA N., NEGRE F., NAGEGOWDA D. A., ORLOVA I. Plant Volatiles: Recent Advances and Future Perspectives. Cri. Rev. Plant Sci. 25, 417, 2006.

36. THOMPSON G. A., GOGGIN F. L. Transcriptomics and functional genomics of plant defence induction by phloem- 
feeding insects. J. Exp. Bot. 57, 755, 2006.

37. PIESIK D., WENDA-PIESIK A., LIGOR M., BUSZEWSKI B., DELANEY K. J. Dock leaf beetle, Gastrophysa viridula, herbivory on mossy sorrel, Rumex confertus: Induced plant volatiles and beetle orientation responses. J. Agric. Sci. 4, 97, 2012.

38. PIESIK D., LEMAŃCZYK G., SKOCZEK A., LAMPARSKI R., BOCIANOWSKI J., KOTWICA K., DELANEY K. J. Fusarium infection in maize: Volatile induction of infected and neighboring uninfected plants has the potential to attract a pest cereal leaf beetle, Oulema melanopus. J. Plant Physiol. 168, 1534, 2011.

39. CARROLL M. J., SCHMELZ E. A., MEAGHER R. L., TEAL P. E. A. Attraction of Spodoptera frugiperda larvae to volatiles from herbivore-damaged maize seedlings. J. Chem. Ecol. 32, 1911, 2006.

40. BRUCE T. J. A., PICKETT J. A. Perception of plant volatile blends by herbivorous insects - finding the right mix.
Phytochemistry 72, 1605, 2011.

41. TASIN M., BÄCKMAN A.-C., CORACINI M., CASADO D., IORIATTI C., WITZGALL P. Synergism and redundancy in a plant volatile blend attracting grapevine moth females. Phytochemistry 68, 203, 2007.

42. HEIL M., KARBAN R. Explaining evolution of plant communication by airborne signals. Trends Ecol. Evol. 25, 137, 2010.

43. TURLINGS T. C. J., TON J. Exploiting scents of distress: the prospect of manipulating herbivore-induced plant odours to enhance the control of agricultural pests. Curr. Opin. Plant Biol. 9, 421, 2006.

44. DICKE M., BALDWIN I. T. The evolutionary context for herbivoreinduced plant volatiles: beyond the 'cry for help'. Trends Plant Sci. 15, 167, 2010.

45. BOCZEK J., KIEŁKIEWICZ M., KACZMARCZYK A. Herbivore-induced plant volatiles and their potential role in integrated pest management Prog. Plant Prot./Post. Ochr. 